\title{
„NASZ ZDROWY ŚWIAT NIE CHCE ŚWIATA CHOROBY...” O BÓLU I CIERPIENIU W REPORTAŻACH WOJCIECHA TOCHMANA
}

Ból sytuuje się poza słowem. Jest domeną materii, fizjologii, udręczonej i niemej świadomości. Ból to ciemna, nie poddająca się werbalizacji, mowa ciała. Jeśli znajduje swój wyraz, to w wykrzywionej grymasem twarzy, zaciśniętej kurczowo dłoni, bezwiednym jęku lub nieartykułowanym krzyku .

Takimi słowami Krystyna Pietrych rozpoczyna pracę noszącą tytuł Co poezji po bólu. W dalszej części wprowadzenia do rozważań, badaczka doszła jednak do wniosku, że ból nie pozostaje od języka całkowicie niezależny. Uczona stwierdziła, że: „Proces werbalizacji jest niezbędnym składnikiem każdego doświadczenia, do czystego, pozaświadomościowego doznania nie mamy dostępu; słowo współtworzy doświadczenie, jest jego aktywną składową na równi ze świadectwem zmysłów"2. Badaczka zacytowała Derridę, który stwierdził, że choroba powodująca ogromne pokłady bólu jest trudna do opisania słowami, nie można jej przemilczeć i dlatego też należy o niej napisać ${ }^{3}$ Tak też czynili poeci: Aleksander Wat, Zbigniew Herbert, Miron Białoszewski, Stanisław Barańczak, Janusz Szuber, Julian Przyboś oraz Anna Świrszczyńska, którym Pietrych poświęciła kolejne rozdziały w swojej pracy. Poezja, którą stworzyli, jest świadectwem ich cierpienia, jest próbą zmierzenia się z chorobą, próbą pokonania jej, złagodzenia czy też oswojenia.

Susan Sontag natomiast, w eseju zatytułowanym Choroba jako metafora, napisanym $\mathrm{w}$ czasie walki autorki z rakiem piersi, przedstawiła sposób funkcjonowania różnych schorzeń (raka oraz gruźlicy) w tekstach kultury i świadomości człowieka na przestrzeni dziejów. Sontag pokazała również, jak rzeczywistość okropnych niedyspozycji została „niedorzecznie przekształcona”. Autorka skupiła się na dolegliwościach, które można

\footnotetext{
"Joanna Popławska - (rocznik 1988) studentka II roku studiów III stopnia w Instytucie Polonistyki i Kulturoznawstwa Uniwersytetu Szczecińskiego. Przygotowuje rozprawę o szkole reportażu „Gazety Wyborczej”. Jej zainteresowania, konsekwentnie rozwijane w kolejnych pracach dyplomowych, koncentrują się wokół najnowszej literatury reportażowej. Publikowała między innymi w pismach: „Studenckie Zeszyty Naukowe Uniwersytetu Jagiellońskiego”, a także w zbiorach studiów i tomach pokonferencyjnych.

${ }^{1}$ K. Pietrych, Co poezji po bólu, Łódź 2009, s. 7.

${ }^{2}$ Tamże, s. 15.

${ }^{3}$ Tamże, s. 25.

${ }^{4}$ S. Sontag, Choroba jako metafora [Fragmenty], przekł. J. Anders, [w:] Osoby. Transgresje 3, red. M. Janion, Gdańsk 1984, s. 219.
} 
by nazwać „modnymi” w danym czasie, mówiła o genezie ich popularności, o tym, czego są metaforą i dlaczego. I tak na przykład nowotwór oraz gruźlica w czasach mitologicznych były pojmowane jako choroby namiętności. W dobie romantyzmu gruźlica zaczęła być tłumaczona jako jeden z wariantów choroby miłosnej, gdyż powstawała ponoć z nadmiaru pożądania. Oprócz gruźlicy, która „stała się synonimem romantyczności już $\mathrm{w}$ połowie osiemnastego wieku" ${ }^{5} \mathrm{i}$ nowotworu, autorka wspomniała także o tym, że w tej epoce panowała moda na choroby psychiczne, takie jak na przykład obłąkanie. Romantycy uważali niezdrowy wygląd za błogosławieństwo, a osobę chorą za dużo bardziej atrakcyjną. Sontag zauważyła także, że według Greków choroba była karą nadprzyrodzoną i najczęściej występowała w formie opętania przez demony ${ }^{6}$. Pierwsi chrześcijanie uznawali natomiast, że choroba to forma składania ofiary za grzechy, których człowiek się dopuścił.

Twórczość Wojciecha Tochmana - jednego z głównych przedstawicieli współczesnego reportażu, od lat związanego z "Gazetą Wyborczą", autora wielu cenionych książek i setek tekstów publikowanych na łamach między innymi wymienionego dziennika oraz będącego jego dodatkiem „Dużego Formatu” — oscyluje wokół zagadnień bólu, cierpienia oraz choroby. Dziennikarz, od lat opisujący ludzkie krzywdy, niesprawiedliwość i okrucieństwo losu, pochyla się nad tymi, którzy doznali w życiu męki. Spisuje ich dzieje po to, by został w końcu wysłuchany i zauważony przez innych ludzi, aby wzbudził w nich refleksję nad istotą bytu.

Analizując poruszaną przez pisarza tematykę, rozpoczynając od jego „polskich” zbiorów reportaży, które są najistotniejsze dla obecnych rozważań, czyli Schodów się nie pali oraz Wściekty pies, a następnie przechodząc do publikacji traktujących o ludziach zamieszkujących inne, często dużo biedniejsze kraje, nie sposób nie zauważyć, iż nieszczęście dotknęło zdecydowaną większość bohaterów tekstów autora. Czy więc był to pojedynczy człowiek, taki jak dwudziestoletni Jakub z zespołem Tourette’a (W'siekly pies), czy Josephine Vergara — kobieta, której ciało zostało zdeformowane przez setki narośli (Eli, Eli), czy pewna zbiorowość: muzułmanie i Serbowie (Jakbyś kamień jadła), mieszkańcy Rwandy (Dzisiaj narysujemy śmierc), mieszkańcy slumsów Manili $(E l i, E l i)$, pewne jest to, że czytelnik będzie musiał zmierzyć się z historiami ludzi, których życie przepełnione jest bólem, cierpieniem, którym doskwierały rozmaite, często nieuleczalne i jeszcze niesklasyfikowane schorzenia. Tochman nie potrafi od cierpienia uciec, zdystansować się, skupić się na tematach lżejszych, bo jak stwierdził Tadeusz Gadacz:

Cierpienie jest jednym z najbardziej dominujących doznań życiowych. Choć niepojęte i jakże często trudne do udźwignięcia, splecione jest z życiem w sposób nierozdzielny. Nie jest jakimś szczególnym przypadkiem, który się przytrafia, ale czymś, bez czego życie nie byłoby możliwe. Każdy wcześniej czy później doznaje cierpienia, gdyż jest ono ceną, jaką płacimy za życie. Od cierpienia nie można uciec ${ }^{7}$.

\footnotetext{
${ }^{5}$ Tamże, s. 216.

${ }^{6}$ Tamże, s. 220.

${ }^{7}$ T. Gadacz, Enigma cierpienia, [w:] tenże, O umiejętności życia, Kraków 2004, s. 199.
} 
Tochman od choroby nie tylko nie mógł się uwolnić, ale sam zauważał, o czym napisał w zbiorze reportaży Eli, Eli, że rozmaite dysfunkcje w jakiś niezrozumiały sposób przyciągają jego uwagę, sprawiają, że reporter nie mógł odwrócić od nich wzroku, niemalże same mu się narzucały, epatowały swoją brzydotą, pragnęły być oglądane:

Żywe, ciepłe, wilgotne, wydające zapach zdrewniałe ciało nieznajomej kobiety. Nie chcielibyśmy go dotknąć. Spurchlała skóra każe nam się cofnąć. Ale nie odwrócić. Bo porośnięte czymś ciało przykuwa naszą uwagę. Jesteśmy go ciekawi. Choroba odebrała mu już widoczne znamiona płci, wiek, rasę, urodę, uśmiech, grymas, spojrzenie, radość, pragnienia i $\operatorname{moc}^{8}$.

Choroba stanowi uniwersum rozważań Tochmana, bo jest obecna wszędzie, dotyczy wszystkich ludzi, nie sposób przed nią uciec, jej ominąć, nie zauważyć. Choroba jest też jedyną rzeczą, wobec której wszyscy są równi.

Tochman w zbiorach reportaży W'sciekty pies oraz Schodów się nie pali opisał doświadczenia choroby, ale nie w takim wymiarze, w jakim zrobiła to Sontag. Reporter skupił swoją uwagę na schorzeniach nietypowych, rzadko spotykanych, czasem nawet nieznanych. Takich, które nie znalazły jeszcze swojego opisu w innych dziełach literackich, gdyż nie były aż tak ,atrakcyjne” i spopularyzowane. Autor nie pisał również o swoich doświadczeniach, ale przedstawił historie innych ludzi. Tych, którzy sami nie mogli tego zrobić z powodu licznych dysfunkcji, uniemożliwiających im normalne życie. Bo czy mężczyzna ze zdiagnozowanym zespołem Tourette'a, niemogący spokojnie usiąść i zjeść posiłku nie rozrzucając wszystkiego wokół, który nie potrafi nalać sobie filiżanki herbaty, żeby nie rozlać jej po stole, byłby w stanie spisać swoje uczucia i doświadczenia? Czy dziecko, które ma tak bardzo niewykształcone organy, że dopiero w wieku kilku lat powoli uczy się samo chodzić, jeść, ubierać, jest w stanie dać świadectwo tego, czym jest jego choroba? Czy też może dorosły, pięćdziesięcioletni mężczyzna, ze stwierdzoną amnezją, jest w stanie wyrazić na piśmie, jak to jest, gdy pewnego dnia człowiek budzi się nie znając swojej tożsamości? Żaden z bohaterów Wojciecha Tochmana nie był w stanie tego zrobić. Dlatego właśnie autor podjął się zadania polegającego na tym, żeby poprzez swoje reportaże uzmysłowić czytelnikom, jak wygląda życie jednostki zdeterminowane nieuleczalnym schorzeniem.

W zbiorach Wśsiekty pies oraz Schodów się nie pali znalazło się kilka tekstów, wymagających szczególnej uwagi i traktujących o doświadczeniu choroby. Są nimi tytułowy utwór Schodów się nie pali oraz dwa teksty należące do zbioru Wściekty pies: Więzień oraz Człowiek, który powstał z torów. Tochman nie zajął się tu przedstawieniem chorób zwyczajnych, codziennych, z którymi można „normalnie” żyć i funkcjonować. Opisał zmagania ludzi, którym choroba zdeterminowała życie, doprowadziła do tego, że egzystują w więzieniu, którym jest ich własne ciało. Są w dużym stopniu samotni, wyobcowani, wykluczeni ze zbiorowości. Co jednak najgorsze, nie mają oni szans na poprawę swojej sytuacji i na wyzdrowienie.

W reportażu pod tytułem Więzień bohaterem jest dorosły już dziś mężczyzna o imieniu Jakub. Tochman najpierw krótko nakreślił jego dzieciństwo. Napisał, iż

\footnotetext{
${ }^{8}$ W. Tochman, Eli, Eli, Wołowiec 2013, s. 9.
} 
był on zwyczajnym, wesołym dzieckiem, które cieszyło się życiem i normalnie się rozwijało:

Jest jedynym ukochanym synkiem swoich rodziców. Nazwali go Jakub. Ma siedem, może osiem lat i kłopoty ze zdrowiem. Ale jeszcze nie wie, że dwadzieścia lat później będzie całymi dniami leżał na łóżku obok stołu z lepiącą się ceratą. Twarz będzie miał w strupach i świeżych ranach. Będzie się drapał, uderzał głową o kanty, walił pięściami we własny kark albo palce sobie wkładał do oczu [... $]^{9}$.

Tragiczna choroba dziecka rozpoczęła się z dniem, gdy trafiło ono do szpitala z powodu zapalenia wyrostka robaczkowego, który należało usunąć operacyjnie. Jak wspominała mama chłopca, ze szpitala odebrała całkiem inne dziecko, nie było ono już takie, jak dawniej, roześmiane, szczęśliwe. Zaczęło mieć nienaturalne nerwowe tiki, ale jeszcze nie tak silne, jak w okresie późniejszym. Potem stan chłopca pogorszył wyjazd wakacyjny z dziadkiem. Dziecko złapało infekcję, która nasiliła niepokojące objawy nieznanej jeszcze wtedy choroby. Po pewnym czasie zdiagnozowano u chłopca: „[...] zespół Tourette’a. Mruganie, wzruszanie ramionami, grymasy twarzy — to klasyczne objawy. [...] Ale tourette, który mieszkał w Jakubie, wciąż schodził niżej: chłopiec zaczął podskakiwać, kopać” ${ }^{10}$. Od tego czasu Kuba nie był już sobą, rządziła nim choroba, która nigdy nie miała go już opuścić. Mężczyzna jednak nigdy nie utracił swojej świadomości, wiedział, że już nie wyzdrowieje, chociaż początkowo lekarze obiecywali, że po okresie dojrzewania tiki powinny się zmniejszyć i choroba zazwyczaj w większości wypadków całkowicie ustępuje. Tak jednak się nie stało. Zdawał sobie sprawę ze swoich niekontrolowanych zachowań, z tego, że nie tylko słowem krzywdził swoich rodziców. Czasem żałował również swoich czynów, przepraszał za okropne zachowanie, ale nie był w stanie tego zmienić, choroba zwyciężała. Miał jednak nadzieję, że może kiedyś, pewnego dnia będzie mógł wyjść sam na ulicę, zjeść normalnie posiłek, spotkać się z kobietą.

Jego choroba psychiczna nie pozwalała mu myśleć pozytywnie, nie dodawała mu odwagi w walce o normalne funkcjonowanie. Nie miał żadnej szansy na choć odrobinę szczęścia i poczucia ulgi, którą chociażby wyczytać można z dzienników z czasu choroby Krystyny Kofty. W zapiskach Lewa, wspomnienie prawej autorka przedstawiła czytelnikowi swoje zmagania z nowotworem piersi. I choć rak większości ludzi kojarzy się z wyrokiem, Kofta starała się podchodzić do choroby z dystansem i pozytywnym nastawieniem. Nie pozwoliła się zniewolić, przywiązać do łóżka i pożegnać z normalnym życiem. Nadal, nawet podczas chemioterapii, uczestniczyła w życiu kulturalnym, pisała felietony do „Twojego Stylu”, chodziła na bankiety, udzielała wywiadów. Na pewnym etapie leczenia stwierdziła nawet, że choroba zmieniła coś w jej życiu, że dała jej poczucie wolności ${ }^{11}$.

Jednak takich odczuć, o jakich pisała Kofta, nie mógł mieć Jakub. Jego choroba była inna, atakowała nie tyle narządy wewnętrzne, co układ nerwowy człowieka.

\footnotetext{
${ }^{9}$ W. Tochman, Więzień, [w:] tenże, Wściekty pies, Kraków 2007, s. 47.

${ }^{10}$ Tamże, s. 51.

${ }^{11}$ K. Kofta, Lewa, wspomnienie prawej, Warszawa 2009, s. 173.
} 
Chłopak musiał zrezygnować z nauki, bo nauczyciele sobie z nim nie radzili, nie mógł podjąć żadnej pracy, choć był sprawny fizycznie, nie miał przez to żadnej okazji do nawiązywania jakichkolwiek kontaktów z innymi ludźmi. Czuł się coraz bardziej samotny i wyobcowany, ludzie nie rozumieli go i nie tolerowali jego inności. Gdy wychodził z rodzicami na ulicę, skupiał na sobie uwagę wszystkich. Niektórych śmieszył, innych irytował i bulwersował swoim zachowaniem. Bał się ich, dlatego wolał zostawać w domu, gdzie czuł się bezpiecznie, gdzie spędził ostatnie dwadzieścia lat swojego życia. Wolał leżeć na łóżku obok stolika nakrytego ceratą, niż wychodzić na zewnątrz: „Leży. Jak wczoraj, przedwczoraj, tydzień temu i pięć lat temu"12. Kuba już dawno przestał interesować się światem:

Nie obejrzy telewizji, bo świat nie będzie go już interesował. Będzie wydawał mu się zły, wrogi, obcy. I będzie to prawda, bo świat nie toleruje kogoś, kto nagle i bez powodu krzyczy tak głośno, jak chyba żaden inny człowiek nie potrafi krzyczeć. Świat nie lubi kogoś, kto szczeka, ryczy ${ }^{13}$.

Żył w domu jak w więzieniu, choć drzwi były otwarte i nikt go w mieszkaniu siłą nie zatrzymywał. Mimo wszystko: „Jakub wciąż wierzy, że może tym razem ktoś go od tourett'a uwolni. Kiedy o tym myśli, oczy mu się weselą" ${ }^{14}$. Kiedy Kuba nie spał, choroba nie dawała mu spokoju, mężczyzna był wtedy agresywny, krzyczał, skakał, ryczał, wszystko rozlewał, niszczył, natomiast kiedy spał, tourette spał razem z nim, dawał mu odpocząć, żeby po przebudzeniu zgotować mu oraz jego rodzinie piekło.

Sytuację, w jakiej znalazł się Jakub, można porównać do równie smutnej historii Trędowatego z Aosty, którą znajdziemy w Opowiadaniach zebranych Gustawa Herlinga-Grudzińskiego. Narrator przedstawił sylwetkę mężczyzny, który w wieku dwudziestu lat został zamknięty w wiėzy na skraju włoskiego miasteczka. Miał on żyć tam samotnie, z dala od zdrowych mieszkańców, aż do śmierci. Jak napisał autor: „Około roku 1782 Wieżę Strachu odrestaurowano i otoczono jak obrożą murem przewyższającym znacznie rosłego mężczyznę, by dać w niej schronienie trędowatemu i odizolować go całkowicie od świata" ${ }^{15}$. Mężczyzna, który znalazł się w tym więzieniu, czuł się samotny, gdyż przez całe swoje życie spędzone w odosobnieniu rozmawiał tylko raz z przypadkowym przechodniem. Trędowaty w swojej pustelni doznawał uczuć, których nikt, kto nie znalazł się w jego sytuacji, nie mógł zrozumieć. Mimo wszystko starał się odnaleźć pozytywne aspekty swojego samotnego życia. Jak sam twierdził: „-Ten kto kocha swoją celę — odparł Trędowaty — znajdzie w niej spokój”" ${ }^{16}$. Nauczył się szukać szczęścia i osiągać spełnienie, będąc równocześnie wykluczonym z życia społecznego. Bywały dni szczególnie ciężkie dla bohatera opowiadania, ale szybko mijały i ustępowały tym, które pozwalały mu zaznać spokój i ukojenie.

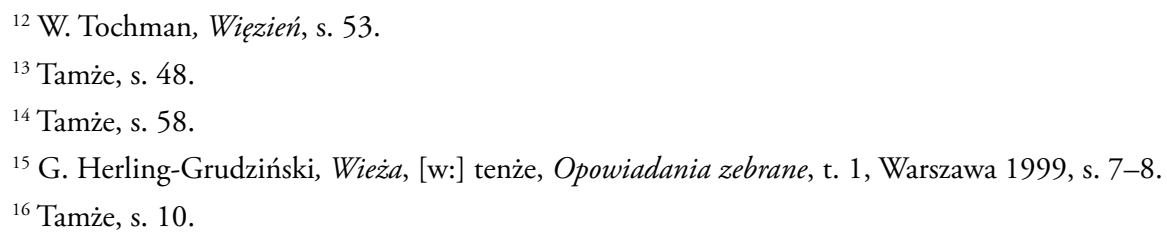


Równie tragiczny obraz maluje się w reportażu Schodów się nie pali. Tochman przybliżył tu czytelnikowi postać małego Mateuszka, który urodził się oszpecony. Jego biologiczna matka nie potrafiła udźwignąć takiego ciężaru, dlatego też postanowiła oddać chłopca do domu dziecka. Początkowo wszyscy się go bali, uważali go za potwora:

[...] ludzie szeptali przez płoty: głowę miał wielką i pomarszczoną. Ślepia wyłupiaste, bez powiek. A palce żabie. I łuskę na całym ciele, jak u ryby. Byli tacy, którzy wiedzieli, skąd ta brzydota: — nie od Pana Boga. Alarmowali: — Nasze krowy przestały dawać mleko ${ }^{17}$.

Po jego narodzinach lekarze nie potrafili postawić diagnozy. Nie znali wcześniej takich przypadków. Stwierdzili, że chłopiec nie widział i nie słyszał. Uznali, że po prostu pewnego dnia dziecko zaśnie i już nigdy się nie obudzi. Miał wielkie usta, wytrzeszczone gałki oczne, szczątkowe małżowiny uszne, oczopląs, suchą i szorstką skórę, brakowało mu powiek, brwi i owłosienia. W końcu specjaliści potrafili nazwać chorobę: Ableharon Macrostomia Syndrome, co oznaczało zespół braku powiek i ogromne usta ${ }^{18}$. Oprócz wad fizycznych, z jakimi się urodził Mateusz — bo tak nazwali go opiekunowie z domu dziecka — był także opóźniony umysłowo. Na swojej drodze małoletniego życia spotkał jednak dobrych ludzi, którzy przyzwyczaili się do niego i zaopiekowali się chłopcem. W ośrodku, w którym przebywał, poznał Renatę, samotną matkę wychowującą siedemnastoletnią córkę. Los tak się ułożył, że kobieta postanowiła wraz z siostrą adoptować dziecko i stworzyć mu prawdziwy dom. Pomimo wielu starań kobiet i rehabilitacji nie rozwijało się ono tak jak powinno, jednak robiło spore postępy.

Mateuszek nie do końca zdawał sobie sprawę ze swojej inności i kalectwa. Nie widział różnic między sobą a innymi dziećmi. Nie rozumiał zainteresowania swoją osobą, poruszenia wśród ludzi obcych, kiedy się pojawiał. Wszędzie musiał być pod opieką swoich matek zastępczych, nie potrafił sam się ubrać, ani zjeść. Ludzie, którzy go nie znali, bali się i odtrącali go. Świat nie tolerował chłopca, uważał go za potwora: „Ktoś podsumował: - Trzeba mur wokół domu postawić, wnuki schować" ${ }^{19}$. Choć dziecko w domu Doroty i Renaty czuło się szczęśliwe i kochane, to i tak żyło tylko w wyodrębnionej przestrzeni, poza którą nie mogło wychodzić.

Dwa przedstawione reportaże mają zdecydowanie pesymistyczną wymowę. Inaczej jest z trzecim tekstem noszącym tytuł Człowiek, który powstał z torów. Choć prezentuje on poważne schorzenie, jakim jest amnezja wsteczna, to jednak historia Jana Mana skończyła się szczęśliwie. Tytuł tego tekstu jest zarówno metaforyczny, jak i dosłowny, co zauważyła Magdalena Piechota w szkicu Strategie nadawcze w reportażach Wojciecha Tochmana. Jest on więc aluzją do biblijnego określenia człowieka, który powstał z prochu, albo też dosłownym obrazem przedstawiającym Jana Mana, który pewnego dnia

\footnotetext{
${ }^{17}$ W. Tochman, Schodów się nie pali, [w:] tenże, Schodów się nie pali, Kraków 2000, s. 25.

${ }^{18}$ Tamże, s. 27.

${ }^{19}$ Tamże, s. 36.
} 
obudził się na torach kolejowych z całkowicie wymazaną pamięcią ${ }^{20}$. Bohater reportażu nie wiedział po przebudzeniu, jak ma na imię, skąd pochodził, co robił na torach, w jakim był wieku. Nie pamiętał żadnych faktów ze swojego życia, nie rozumiał, co się stało z jego pamięcią. Mężczyzna znalazł się nagle w obcym dla siebie środowisku, nie potrafiąc w nim funkcjonować: „[...] — Weź wiadro i przynieś prądu — robotnicy na budowie wydawali mu takie polecenia. Janek brał wiadro, wychodził za płot, pytał ludzi we wsi, gdzie może prąd znaleźć, bo kazali mu przynieść całe wiadro"21. Wszystkiego musiał nauczyć się od nowa. Nauka ta przychodziła mu szybko:

Był głodny. Szybko nauczył się, że za jedzenie trzeba płacić pieniędzmi, które ludzie wyjmują z torebek, aktówek albo kieszeni. Miał kieszenie, więc sięgnął do nich, ale pieniędzy tam nie znalazł. Tylko zapalniczka była i metalowy aniołek. Tyle zostało z jego poprzedniego życia, od którego w jakiś niezrozumiały sposób jakaś okrutna siła postanowiła go odgrodzić, odizolować, odciąć $[\ldots]^{22}$.

Nie miał stałego miejsca zamieszkania, tułał się po lasach, sadach, spał tam, gdzie mógł. Niektórzy ludzie odnosili się do niego ze współczuciem i mu pomagali, inni szydzili z niego i uważali go za niebezpiecznego. Na szczęście spotkał na swojej drodze dobrych ludzi, którzy otoczyli go opieką medyczną, pomogli mu otrzymać nowe dokumenty tożsamości, dali mu drugie życie:

[...] Jan jest dobrym, skrzywdzonym przez los człowiekiem. Zalęknionym z powodu tego, co przeszedł. Jan nie wie, kim jest, nie pamięta twarzy rodziców, tak samo nie wie, że są kontynenty i był Napoleon. Nie ma pojęcia o starożytnej Grecji ani o filozofii. Wielu rzeczy nie wie nasz Jan. Ale widzi sens życia i śmierci, jest życzliwy ludziom i rozumie ich ${ }^{23}$.

Zagadnieniem choroby w literaturze zajmowali się już starożytni, dlatego też Tochman nie jest pierwszym autorem, który przedstawia zmagania człowieka z jej smutnym obliczem. Śledząc historie opisywane przez reportażystę oraz przez innych pisarzy należy stwierdzić, iż różnie definiowane ból i cierpienie mają wymiar uniwersalny. Nie są one jedynie domeną starości, ale dotyczą ludzi w każdym wieku i są obecne w każdej kulturze. Autorzy wszystkich epok prezentowali więc w swoich dziełach jednostki chorobowe, które dotykały pojedynczych postaci, bądź całych zbiorowości. Opisywali przypadłości lekkie, niegroźne i ciężkie, przewlekłe, które często prowadziły do śmierci. Czasem bohaterom utworów udawało się wyzdrowieć, innym razem byli nieuleczalnie chorzy, a nawet zdarzało się, że dane im było umrzeć. Literaci swoją twórczością dowodzili, że wobec bólu i cierpienia oraz śmierci wszyscy ludzie są równi. Jak pokazuje nie tylko literatura, ale również inne dzieła kultury, choroba nie oszczędza

\footnotetext{
${ }^{20}$ M. Piechota, Strategie nadawcze w reportażach Wojciecha Tochmana, [w:] Oblicza Komunikacji 1. Perspektywy badań nad tekstem, dyskursem i komunikacją, t. 2, red. I. Kamińska-Szmaj, T. Piekot, M. ZaśkoZielińska, Kraków 2006, s. 573.

${ }^{21} \mathrm{~W}$. Tochman, Człowiek, który powstat z torów, [w:] tenże, Wściekty pies, s. 74.

${ }^{22}$ Tamże, s. 72.

${ }^{23}$ Tamże, s. 85.
} 
nikogo, każdy człowiek w swoim życiu na którymś z jego etapów doświadcza różnych wymiarów cierpienia.

Wojciech Tochman jednak w wyjątkowy sposób postanowił zmierzyć się z tym tematem często poruszanym przez literatów. Wybrał historie takich ludzi, którzy sami nie mogli dać świadectwa swoich przeżyć. Opisywał cierpienie jednostek w każdym wieku, wywodzących się z różnych warstw społecznych. W omówionych reportażach przybliżył czytelnikom losy przede wszystkim tych, którzy z powodu swoich dysfunkcji nie byli nawet w stanie dokładnie opowiedzieć tego, co czuli i jak im ciężko walczyć przez całe życie ze swoimi schorzeniami (z wyjątkiem Jana Mana). Dlatego też autor napisał o ich zmaganiach, korzystając z informacji zaczerpniętych od osób z najbliższego otoczenia chorych oraz ze swych obserwacji. Taką próbę przedstawienia choroby można uznać za nowatorską. Niewiele mógł przecież powiedzieć autorowi mężczyzna chory na zespół Tourette’a czy też mały chłopiec, którego ledwo rozumiały jego matki zastępcze. Tochman opisał zatem ich schorzenia na podstawie wywiadów, których udzielili mu opiekunowie. Dzięki temu reporter mógł przedstawić nie tylko dramat bohaterów swoich tekstów, ale także ich rodzin, na które choroba dzieci wywarła ogromny wpływ.

Reporter podejmując temat choroby ukazał również problem izolacji postaci swoich opowieści. Z powodu dysfunkcji zmuszeni oni byli do życia w samotności. Choroba sprawiła, że zostali odrzuceni przez społeczeństwo i mogli liczyć jedynie na pomoc ze strony najbliższych. Z tym problemem musiał się zmierzyć i Mateuszek, nazywany przez lokalną społeczność „potworem”, i Jakub, który za każdym razem, gdy wychodził z domu, wzbudzał w przechodniach zgorszenie, wrogość, śmiech lub też oburzenie. Przez chorobę skazani zostali na codzienną walkę, która miała trwać do końca ich życia. Stracili oni całkowicie szanse na normalne relacje z innymi ludźmi.

Joanna Popławska

\section{“Our Wholesome World Doesn't Want the World of Diseases...” About Pain and Suffering in the Light of Wojciech Tochman's reportages}

Summary

The article presents considerations on the staggering picture of the world and tragedies of ordinary people which are depicted in the works of the most eminent contemporary reporter - Wojciech Tochman. He is the author whose texts abound in suffering and loneliness of a single man, which bring chaos to the orderly life of a reader. The analysed reportages are about the people who are unable to talk on their own about everyday distress due to their rare disfunctions. The text will be an attempt to draw the boundaries of human suffering. Moreover, it will also seek an answer to the questions whether there exists social approval consent for suffering these days or whether the illness discourse still encounters lack of acceptance. The starting point for the analysis will be the early works of Wojciech Tochman included in the following publications: Schodów się nie pali and W'sciekty Pies.

Słowa kluczowe: reportaż, Wojciech Tochman, choroba, ból, cierpienie

Keywords: reportage, Wojciech Tochman, disease, pain, suffering 